\title{
Implications of alcoholic cirrhosis in atherosclerosis of autopsied patients
}

\author{
Luciano Alves Matias da Silveira $^{1 *}$, Bianca Gonçalves Silva Torquato ${ }^{1}$, Mariana Silva Oliveira ${ }^{1}$, Guilherme Ribeiro Juliano ${ }^{1}$, \\ Lívia Ferreira Oliveira ${ }^{1}$, Camila Lourencini Cavellani ${ }^{1}$, Luciana Santos Ramalho ${ }^{1}$, Ana Paula Espindula ${ }^{1}$, \\ Vicente de Paula Antunes Teixeira ${ }^{1}$, Mara Lúcia Fonseca Ferraz ${ }^{1}$
}

${ }^{1}$ General Pathology Sector, Biological and Natural Sciences Institute (ICBN), Universidade Federal do Triângulo Mineiro (UFTM), Uberaba, MG, Brazil

Study conducted at the General Pathology Division, Universidade Federal do Triângulo Mineiro (UFTM), Uberaba, MG, Brazil

Article received: 6/29/2016 Accepted for publication: 10/19/2016

*Correspondence: Disciplina de Patologia Geral, Instituto de Ciências Biológicas e Naturais, UFTM Address: Av. Frei Paulino, 30 Uberaba, MG - Brazil Postal code: 38025-180 drluciano@hotmail.com

http://dx.doi.org/10.1590/1806-9282.63.04.336

\section{SUMmARY}

Introduction: Alcoholism is a major public health problem, which has a high social cost and affects many aspects of human activity. Liver disease is one of the first consequences of alcohol abuse, and steatosis, liver cirrhosis and hepatitis may occur. Other organs are also affected with pathological changes, such as pancreatitis, cardiomyopathies, dyslipidemias and atherosclerosis.

Objective: To identify the occurrence and degree of atherosclerosis in alcohol-dependent individuals with liver cirrhosis, observing macroscopic and microscopic changes in lipid and collagen deposits and in the liver. We also aimed to verify the association of lipid and collagen fiber deposits with gender, age and body mass index, and to relate alcoholism, liver cirrhosis and atherosclerosis.

Method: We performed a study based on autopsy reports of patients with alcoholic liver cirrhosis, with analysis of aorta and liver fragments to verify the occurrence and degree of atherosclerosis, as well as collagen contents.

Results: Microscopic atherosclerosis was higher in young subjects (early injury) and in patients with alcoholic liver cirrhosis. The macroscopic analysis of atherosclerosis in aortas showed that patients in more advanced age groups presented more severe classifications. Atherosclerosis, both micro and macroscopically, and the percentage of fibrosis in the liver and aorta were more expressive in females.

Conclusion: Cirrhotic patients presented a higher percentage of fibrosis and lipidosis, and may represent a group susceptible to the accelerated progression of cardiovascular diseases. Investigative studies contribute to targeting health-promoting interventions, reducing the mortality and costs of treating cardiovascular disease.

Keywords: atherosclerosis, alcoholic liver cirrhosis, autopsy.

\section{INTRODUCTION}

Alcoholism is a major public health problem and has a high social cost, affecting various aspects of human activity. ${ }^{1}$ In the liver, the alcohol produces toxic products such as acetaldehyde and acetic free radicals, highly reactive and potentially damaging to liver cells. ${ }^{2}$ Acetaldehyde is one of the causes of liver fibrogenesis, which triggers an interrelationship between two cell types resident in the hepatic sinusoids: Kupffer cells and stellate Ito cells. ${ }^{3}$

Liver disease is one of the first consequences of alcohol abuse. ${ }^{4,5}$ Some complications include steatosis, liver cirrhosis and hepatitis, but other organs are also affected, with pathological changes such as pancreatitis, cardiomyopathy, cardiac arrhythmias, hypertension, hemorrhagic outbreak, anemia, cancer, immunosuppression, sudden death, dyslipidemia and atherosclerosis. ${ }^{1,6,7}$

These products can interfere with the normal metabolism of other nutrients, particularly lipids, and contribute to liver cell damage. Atherosclerosis is the term used to describe "damage to the large and medium-sized arteries with deposit of yellow plaques containing cholesterol and lipoid material." Such plaques - formed by the proliferation of smooth muscle cells, cholesterol deposition and infiltration of mononuclear cells - reduce 
endothelial function, limiting the effective diameter of the vessels, and can also cause thrombosis, which can trigger various kinds of strokes, such as sudden death from myocardial infarction. ${ }^{8}$

Several risk factors have been described for atherogenic development, such as dyslipidemia, hypertension, diabetes, smoking, alcohol abuse and physical inactivity. Lipid profile has been widely studied for its strong association with atherogenesis. ${ }^{9}$ The most characteristic component of atherosclerosis is chronic inflammation of the artery walls, pointing out the importance of inflammation for the severity of the disease. ${ }^{10}$

Regarding the advances in diagnostic and therapeutic areas, cardiovascular disease remains a major cause of mortality worldwide ${ }^{11}$ and, in view of the epidemiological profile of the Brazilian population, further research is essential to identify risk groups and enable interventions to prevent the incidence and progression of these diseases. In addition, current treatment methods must be improved, seeking new therapeutic targets and specific biomarkers that prove to be useful in the medical practice. Classic research related to the circulatory system mainly involves histopathologic descriptions of pathophysiological processes. ${ }^{11}$

Our study aimed to quantify collagen fibers in the aorta and liver of autopsied patients with and without alcoholic cirrhosis, and to associate the percentage of these fibers with the degree of atherosclerosis, age and BMI of patients, in order to validate the hypothesis that patients with cirrhosis have a higher degree of atherosclerosis and higher percentage of collagen fibers both in the liver and in the aorta.

\section{Method}

This study was approved by the Ethics Committee of the Federal University of Triângulo Mineiro (UFTM, in the Portuguese acronym), under number 888 .

The sampling comprised 30 samples of aorta and 30 of liver from autopsies routinely performed at the Clinical Hospital of the Federal University of Triângulo Mineiro, in the city of Uberaba, State of Minas Gerais, between 1983 and 2008. The information and the fragments were collected by two pathologists responsible for the autopsies performed by the Division of General Pathology of the Clinical Hospital of the UFTM.

Based on autopsy reports, 15 patients were selected, aged over 18 years and with alcoholic liver cirrhosis. For the control cases, 15 patients without alcoholic cirrhosis were selected, matched for gender, color and age and with no cardiovascular disease, autopsied at the same period. Thirty aortic fragments were removed transversely, mea- suring about $20 \times 1 \mathrm{~mm}$, and 30 liver fragments of the right lobe were collected, with approximately $2 \times 2 \mathrm{~cm}$.

As a contributor to the nutritional assessment of patients, the body mass index (BMI) was calculated using the following formula: weight $(\mathrm{kg}) /$ height $^{2}(\mathrm{~m})$. Patients were classified according to BMI as underweight (BMI less than $18.5 \mathrm{~kg} / \mathrm{m}^{2}$ ), normal (between 18.5 and $24.99 \mathrm{~kg} / \mathrm{m}^{2}$ ), overweight (between 25.0 and $29.99 \mathrm{~kg} / \mathrm{m}^{2}$ ) or obese (over $30.0 \mathrm{~kg} / \mathrm{m}^{2}$ ). For this classification, the standards of the World Health Organization were applied (WHO, 2004).

\section{Macroscopic analysis of the aorta}

Macroscopic degree of atherosclerosis was classified into mild, moderate or severe. From this criterion, the observers of this study described quantitatively the atherosclerotic arteriosclerosis. For this evaluation, the extent of atheromatous plaques and the intensity of fibrosis and calcification were considered. ${ }^{12}$

The aortas were evaluated with the aid of a standard scale of $12.0 \mathrm{~cm}$. Each examiner subjectively measured the degree of atherosclerosis using a non-millimetric scale, marking a point on the scale. Next, with a ruler, the distance from 0.0 to the point marked on the scale was measured. The observers standardized atherosclerosis, according to its intensity, categorizing as mild from $0.1 \mathrm{~cm}$ to $4.0 \mathrm{~cm}$, moderate from $4.1 \mathrm{~cm}$ to $7.0 \mathrm{~cm}$, and severe from $7.1 \mathrm{~cm}$ to $12.0 \mathrm{~cm} .{ }^{12}$

\section{Microscopic analysis of aorta and liver fragments}

The slides were stained with hematoxylin and eosin (HE) for semi-quantitative evaluation of lipid deposits, analyzed under common light microscopy. After this analysis, the degree of lipid deposit was classified as mild, when the involvement of the section analyzed was less than $25 \%$; moderate from 26 to $50 \%$, and severe if greater than $50 \%$. The morphological evaluation method of the aortas was adapted from other studies. ${ }^{13,14}$

Slides stained with picro-sirius were used for quantification of collagen fibers in the inner layer of the aorta (Figures 1 and 2) and throughout the extension of the liver cut, examined under polarized light with a 20x objective, final magnification of 800x. The analyses of collagen fibers were performed by morphometric software using the automatic image analysis system KS-300 ${ }^{\circledast}$ (Kontron-Zeiss).

\section{Statistical analyses}

Initially, a Microsoft Excel ${ }^{\circledR}$ spreadsheet was produced and data were analyzed using Graphpad Prism ${ }^{\circledR} 5.0$ software. The normality of the data was checked with Kolmogorov-Smirnov test. Since the distribution was non- 
-normal, we used Mann-Whitney test to compare the two groups and Kruskall-Wallis test for comparison between three or more groups. The Spearman correlation coefficient was used to correlate two variables. Differences were considered statistically significant at $\mathrm{p}<0.05$.

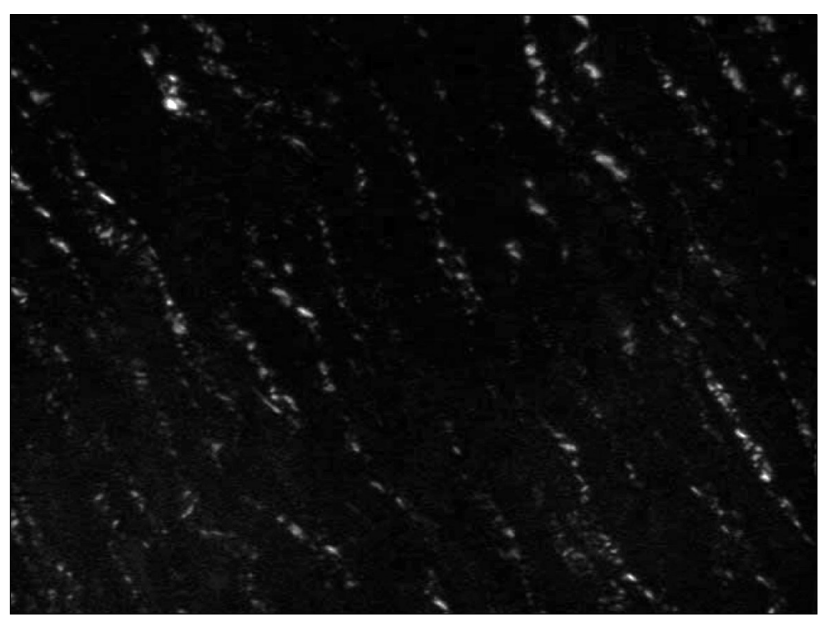

FIGURE 1 Histologic section of the intima layer in human aorta under polarized light, stained with picro-sirius, with end magnification of 800x. Discrete fibrosis is observed.

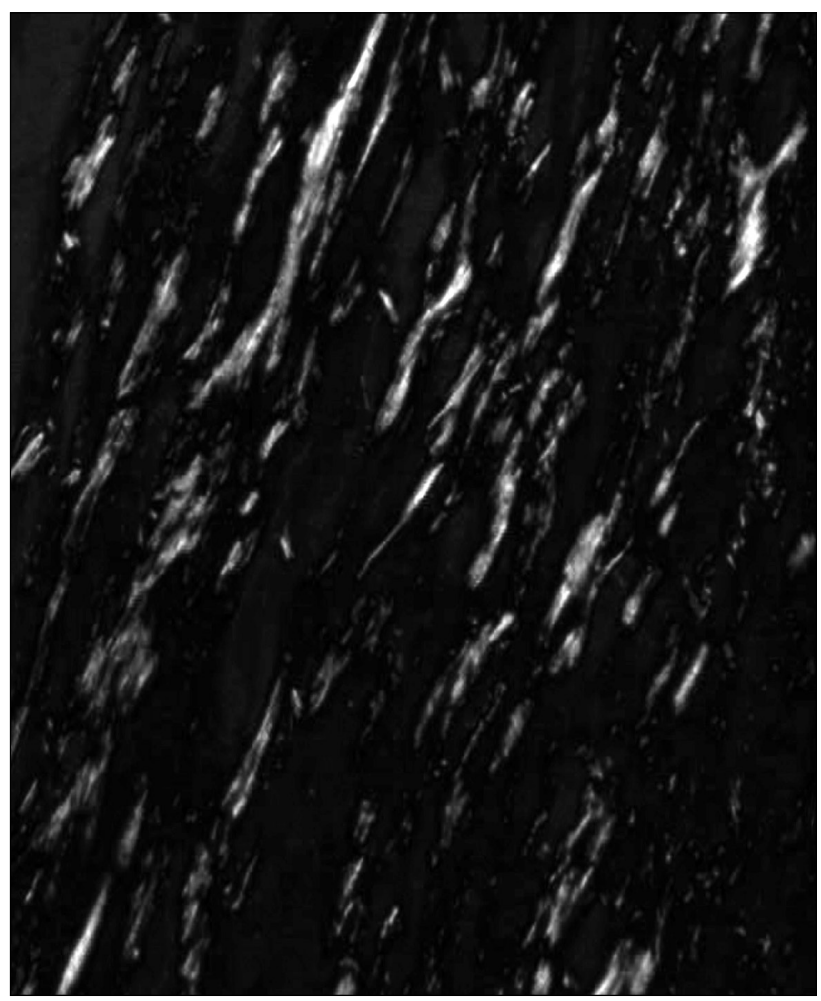

FIGURE 2 Histologic section of the intima layer in human aorta under polarized light, stained with picro-sirius, with end magnification of 800x. Pronounced fibrosis is observed.

\section{Results}

Thirty patients were selected, with 15 cases of alcoholic liver cirrhosis found in the analyzed period, corresponding to $4.2 \%$ of autopsy reports, and 15 without cirrhosis. The patients were divided into four groups: group 1 (mild atherosclerosis, without cirrhosis), group 2 (moderate and severe atherosclerosis, without cirrhosis), group 3 (mild atherosclerosis, cirrhotic), and group 4 (moderate and severe atherosclerosis, cirrhotic). The general characteristics of the samples were analyzed with descriptive methods presented in Table 1.

\begin{tabular}{|c|c|c|c|}
\hline Data & $\begin{array}{l}\text { Cirrhotic } \\
(n=15)\end{array}$ & $\begin{array}{l}\text { Non-cirrhotic } \\
(n=15)\end{array}$ & $\begin{array}{l}\text { Total } \\
(n=30)\end{array}$ \\
\hline \multicolumn{4}{|l|}{ Atherosclerosis } \\
\hline Mild & 10 & 13 & 23 \\
\hline Moderate and severe & 5 & 2 & 7 \\
\hline \multicolumn{4}{|l|}{ Gender } \\
\hline Female & 4 & 5 & 9 \\
\hline Male & 11 & 10 & 21 \\
\hline \multicolumn{4}{|l|}{ Color } \\
\hline White & 12 & 10 & 22 \\
\hline Non-white & 3 & 5 & 8 \\
\hline
\end{tabular}

By associating liver fibrosis with cirrhosis and atherosclerosis, we found that cirrhotic patients with mild atherosclerosis showed a higher percentage of liver fibrosis than cirrhotic patients with moderate and severe atherosclerosis $(\mathrm{p}<0.0001)$.

As for aortic fibrosis, cirrhotic patients had a significantly higher percentage of fibrosis than the non-cirrhotic ones $(p<0.0001)$. Among those with moderate and severe atherosclerosis, the degree of atherosclerosis was higher in cirrhotic patients $(\mathrm{p}<0.0001)$.

Considering the association of BMI with cirrhosis and atherosclerosis, cirrhotic patients with mild atherosclerosis had higher BMI than those with moderate and severe atherosclerosis $(\mathrm{p}=0.0017)$.

Analyzing all patients, in general and in groups, both BMI and macroscopic atherosclerotic severity significantly increased with age ( $\mathrm{p}<0.0001$ for all correlations). However, with advancing age, aortic fibrosis decreased significantly ( $\mathrm{p}<0.0001)$ in groups 3 and 4 (cirrhotic).

In all groups, the BMI increased significantly with liver fibrosis ( $p<0.0001$ for all correlations). The macroscopic degree of atherosclerosis increased significantly with the increase of liver fibrosis in all groups ( $<<0.0001)$. Aortic fibrosis decreased significantly with hepatic fibrosis only in group $3(\mathrm{p}<0.0001)$. 


\section{Discussion}

Our analysis led to the confirmation of the hypothesis that cirrhotic patients have a higher degree of atherosclerosis and aortic fibrosis than non-cirrhotic ones. Furthermore, we observed that liver fibrosis increases with BMI and the intensity of atherosclerosis. This shows a possible link between the two diseases, and the worsening of liver disease could influence the formation of atherosclerotic plaques.

There is increasing evidence that atherosclerosis starts to develop early in life, progressing to more advanced stages since young adulthood. ${ }^{15}$ We also noted a higher degree of atherosclerosis and aortic fibrosis in patients with alcoholic liver cirrhosis. A possible explanation for this would be that the vitamins involved in homocysteine metabolism might be reduced in chronic alcoholism, thus leading to the accumulation of homocysteine, primary indicator of atherogenesis. ${ }^{7}$ Furthermore, it has been discussed that increased levels of homocysteine in patients with alcoholic liver disease also have consequences to the liver, triggering endoplasmic stress ${ }^{16}$ and inhibiting the production of adiponectin, a hormone that induces lipolysis, ${ }^{17}$ stimulates fatty acid oxidation ${ }^{18}$ and inhibits the production of hepatic glucose. ${ }^{19}$

Adipose tissue plays a crucial role in the regulation of fatty acid homeostasis in the entire body. The idea of a dynamic adipose tissue as an endocrine organ is being increasingly recognized, which is very important for the regulation of metabolism in health and disease conditions. Adipocytes secrete proteins called adipokines, such as adiponectin, resistin, Il-6, TNF-alpha, and leptin; ${ }^{20,21}$ and overweight individuals have altered secretion of adipokines, increasing the production of TNF-alpha and IL- 6 by macrophages, which fuels inflammatory processes. ${ }^{22}$ Lifestyle is a significant factor in the development of hepatic steatosis, since it can promote weight gain, ultimately leading to obesity, generating an increase in inflammatory cytokines and insulin resistance that can, in turn, lead to inflammation of visceral fat and increased accumulation of fat in the liver. This cycle of responses of the organism to obesity and the development of hepatic steatosis trigger chronic inflammation (increased C-reactive protein, interleukin 6 and tumor necrosis factor alpha), hypercoagulation, hyperlipidemia (increased levels of triglycerides, decreased HDL-cholesterol levels and possible increased LDL), which increases the risk of heart disease. ${ }^{23}$ This information corroborates our findings, where patients with higher BMI showed a higher degree of cirrhosis and atherosclerosis.

Analysis in the aortas showed that older patients presented more intense macroscopic atherosclerosis. This may be due to progression of the disease; in more advanced stages, there is the formation of fibrous connective tissue, associated with a lipid core, called fibroatheroma. ${ }^{24}$

Regarding fibrosis in the liver of cirrhotic patients, the high incidence may have been a result of repeated use of alcohol. ${ }^{3}$ Triglyceride storage in the form of VLDL is a physiological mechanism that prevents the accumulation of neutral fats in the liver, since VLDL is carried away from the organ. However, excess ethanol causes changes in the triglyceride storage mechanism, and this causes severe cellular stress, resulting in the accumulation of neutral fats in hepatocytes, which can later lead to fibrosis and cirrhosis. ${ }^{25}$

\section{ACKNOWLEDGMENTS}

This study was conducted with grants from Conselho Nacional de Desenvolvimento Científico e Tecnológico (CNPq), Coordenação de Aperfeiçoamento de Pessoal de Nível Superior (Capes), Fundação de Amparo à Pesquisa do Estado de Minas Gerais (Fapemig) and Fundação de Ensino e Pesquisa de Uberaba (Funepu).

\section{Resumo}

Implicações da doença hepática alcoólica na aterosclerose de pacientes autopsiados

Introdução: $\mathrm{O}$ alcoolismo é um grande problema de saúde pública, de elevado custo social e que afeta vários aspectos da atividade humana. Hepatopatia é uma das primeiras consequências do abuso de álcool, podendo ocorrer esteatose, cirrose hepática e hepatite. Outros órgãos, porém, também são afetados, ocorrendo alterações patológicas, como pancreatite, cardiomiopatias, dislipidemias e aterosclerose.

Objetivo: Identificar a ocorrência e a intensidade de aterosclerose em alcoolistas com cirrose hepática, observando alterações macro e microscópicas do depósito lipídico e de fibras colágenas e fígado. Verificar a associação de depósito lipídico e de fibras colágenas com gênero, idade e índice de massa corporal (IMC). Relacionar alcoolismo, cirrose hepática e aterosclerose.

Método: Foi realizado estudo com base em laudos de autópsias de pacientes com cirrose hepática alcoólica, sendo estudados aortas e fígados para verificar a ocorrência e a intensidade de aterosclerose, bem como a quantidade de colágeno encontrada.

Resultados: A aterosclerose microscópica foi maior em jovens (lesão inicial) e em pacientes com cirrose hepática alcoólica. A análise macroscópica da aterosclerose nas aor- 
tas mostrou que pacientes com faixas etárias mais avançadas apresentaram classificações mais intensas. A aterosclerose, tanto micro quanto macroscopicamente, e a porcentagem de fibrose no fígado e na aorta foram mais expressivas no gênero feminino.

Conclusão: Os pacientes cirróticos apresentaram maior porcentagem de fibrose e lipidose, e podem representar um grupo susceptível à acelerada progressão de doenças cardiovasculares. Estudos investigativos contribuem para o direcionamento das intervenções promotoras da saúde, reduzindo a mortalidade e os custos no tratamento das doenças cardiovasculares.

Palavras-chave: aterosclerose, cirrose hepática alcoólica, autópsia.

\section{References}

1. Marchini V. Nutrição clínica: nutrição e metabolismo. São Paulo: Guanabara; 2007.

2. Lieber CS. Relationships between nutrition, alcohol use and liver disease. Alcohol Res Health. 2003; 27(3):220-31.

3. Andrade ZA. As relações entre álcool e fibrose hepática. Arq Méd ABC. 2006; Suppl 2:17-8.

4. Fenoglio LM, Severini S, Ferrigno D, Gollè G, Serraino C, Bracco C, et al. Primary hepatic carcinoid: a case report and literature review. World J Gastroenterol. 2009; 15(19):2418-22.

5. Padoin AV, Staub HL, Chatkin JM, Moretto M, Maggioni L, Rizzolli J, et al. Doença hepática não alcoólica gordurosa e risco de cirrose. Scientia Medica. 2008; 18(4):172-6.

6. Schneider ACR, Pinto RB, Silveira TR. Determinação de risco nutricional e desnutrição por antropometria em crianças e adolescentes com cirrose. Arq Gastroenterol. 2007; 44(4):345-9.

7. Maio R, Dichi JB, Burini RC. Implicações do alcoolismo e da doença hepática crônica sobre o metabolismo de micronutrientes. Arq Gastroenterol. 2000; 37(2):120-4.

8. Carrara CL, Esteves AP, Gomes RT, Guerra LL. Uso da semente de linhaça como nutracêutico para prevenção e tratamento da aterosclerose. Rev Eletrônica Farmácia. 2009; 6(4):1-9.
9. Krause MP, Hallage T, Gama MPR, Sasaki JE, Miculis CP, Buzzachera CF, et al. Associação entre perfil lipídico e adiposidade corporal em mulheres com mais de 60 anos de idade. Arq Bras Cardiol. 2007; 89(3):147-53.

10. Siqueira JP. Revertendo aterosclerose? Rev Fac Cienc Med Sorocaba. 2009; 11(3):41.

11. Zuk N, Dubis J, Witkiewicz W. [The role of proteomics in prognosis and treatment of cardiovascular diseases]. Przegl Lek. 2013; 70(3):143-8.

12. Ferraz ML, Nascimento DMS, Rorato JPH, Espindula AP, Oliveira LF, Ramalho LS, et al. Correlation of lifetime progress of atherosclerosis and morphologic markers of severity in humans: new tools for a more sensitive evaluation. Clinics. 2012; 67(9):1071-5.

13. Zarins CK, Xu C, Glagov S. Atherosclerotic enlargement of the human abdominal aorta. Atherosclerosis. 2001; 155(1):157-64

14. Benvenuti LA, Onishi RY, Gutierrez PS, De Lourdes Higuchi M. Different patterns of atherosclerotic remodeling in the thoracic and abdominal aorta. Clinics (São Paulo). 2005; 60(5):355-60.

15. Nasr N, Ruidavets JB, Farghali A, Guidolin B, Perret B, Larrue V. Lipoprotein (a) and carotid atherosclerosis in young patients with stroke. Stroke. 2011; 42(12):3616-8.

16. Kaplowitz N, Than TA, Shinohara M, Ji C. Endoplasmic reticulum stress and liver injury. Semin Liver Dis. 2007; 27(4):367-77.

17. Song CK, Vaughan CH, Keen-Rhinehart E, Harris RB, Richard D, Bartness TJ. Melanocortin-4 receptor mRNA expressed in sympathetic outflow neurons to brown adipose tissue: neuroanatomical and functional evidence. Am J Physiol Regul Integr Comp Physiol. 2008; 295(2):417-28.

18. You M, Considine RV, Leone TC, Kelly DP, Crabb DW. Role of adiponectin in the protective action of dietary saturated fat against alcoholic fatty liver in mice. Hepatology. 2005; 42(3):568-77.

19. Capeau J. Insulin resistance and steatosis in humans. Diabetes Metab. 2008; 34(6 Pt 2):649-57.

20. Uysal KT, Wiesbrock SM, Marino MW, Hotamisligil GS. Protection from obesity-induced insulin resistance in mice lacking TNF-alpha function. Nature. 1997; 389(6651):610-4.

21. Weisberg SP, McCann D, Desai M, Rosenbaum M, Leibel RL, Ferrante AW Jr. Obesity is associated with macrophage accumulation in adipose tissue. J Clin Invest. 2003; 112(12):1796-808.

22. Neels JG, Olefsky JM. Inflamed fat: what starts the fire? J Clin Invest. 2006; 116(1):33-5.

23. Targher G, Day CP, Bonora E. Risk of cardiovascular disease in patients with nonalcoholic fatty liver disease. N Engl J Med. 2010; 363(14):1341-50.

24. Françoso LA, Coates V. Anatomicopathological evidence of the beginning of atherosclerosis in infancy and adolescence. Arq Bras Cardiol. 2002; 78(1):131-42.

25. Sozio MS, Liangpunsakul S, Crabb D. The role of lipid metabolism in the pathogenesis of alcoholic and nonalcoholic hepatic steatosis. Semin Liver Dis. 2010; 30(4):378-90 